\title{
REVEALING THE WORLD OF ONCOLOGICAL TREATMENT THROUGH DRAMATIC THERAPEUTIC PLAY ${ }^{1}$
}

\author{
Marileise Roberta Antoneli Fonseca², Claudinei José Gomes Campos³, Circéa Amália Ribeiro ${ }^{4}$, Vanessa \\ Pellegrino Toledo ${ }^{5}$ Luciana de Lione Melo ${ }^{6}$
}

\begin{abstract}
${ }^{1}$ Article extracted from the thesis - Understanding the play of the child with cancer through dramatic therapeutic play, presented to the Programa de Pós-Graduação em Enfermagem da Universidade Estadual de Campinas (UNICAMP), in 2014.

${ }^{2}$ M.Sc. in Health Sciences. Campinas, São Paulo, Brazil. Email: roberta_antoneli@yahoo.com.br

${ }^{3}$ Ph.D. in Medical Sciences. Professor of the Programa de Pós-Graduação em Enfermagem at UNICAMP. Campinas, São Paulo, Brazil. Email: ccampos@unicamp.br

${ }^{4}$ Ph.D. in Nursing. Professor of the Programa de Pós-Graduação em Enfermagem at the Universidade Federal de São Paulo. São Paulo, São Paulo, Brazil. Email: caribeiro@unifesp.br

${ }^{5}$ Ph.D. in Nursing. Professor of the Programa de Pós-Graduação em Enfermagem, UNICAMP. Campinas, São Paulo, Brazil. Email: vtoledo@unicamp.br

${ }^{6}$ Ph.D. in Nursing. Professor of the Programa de Pós-Graduação em Enfermagem, UNICAMP. Campinas, São Paulo, Brazil. Email: lulione@unicamp.br
\end{abstract}

\begin{abstract}
This study aimed to understand the play of the preschool child undergoing oncological treatment through dramatic therapeutic play. A total of five preschool age children with cancer participated in the dramatic therapeutic play sessions, between January and May 2013. The material was analyzed using the framework of phenomenology: analysis of the structure of the phenomenon in place. The following categories emerged from the sessions: Immersing oneself in the world of the disease and the oncological treatment; and Remembering the world without the disease. The study learned that becoming ill with cancer is a process which generates pain and suffering for the child, leading her to feel small and fragile in the face of the discomforts of the numerous procedures to which she is subjected. Therapeutic play was an important resource for revealing how the child with cancer feels during the treatment, and showed the children's difficulty in interacting with the unknown, and how this difficulty makes the balance between the points of health and illness complex.

DESCRIPTORS: Child. Cancer. Plays and toys. Pediatric nursing.
\end{abstract}

\section{REVELANDO O MUNDO DO TRATAMENTO ONCOLÓGICO POR MEIO DO BRINQUEDO TERAPÊUTICO DRAMÁTICO}

RESUMO: Objetivou-se compreender o brincar da criança pré-escolar em tratamento oncológico por meio do brinquedo terapêutico dramático. Participaram de sessões de brinquedo terapêutico dramático cinco crianças com câncer, em idade pré-escolar, de janeiro a maio de2013. Procedeu-se a análise do material conforme o referencial da fenomenologia: análise da estrutura do fenômeno situado. Das sessões emergiram as categorias: Mergulhando no mundo da doença e do tratamento oncológico; e Relembrando o mundo sem a doença. O estudo apreendeu que o adoecer com câncer é um processo gerador de dor e sofrimento para a criança, levando-a sentirse pequena e frágil frente aos desconfortos dos inúmeros procedimentos a que é submetida. $\mathrm{O}$ brinquedo terapêutico foi um recurso importante para revelar como a criança com câncer se sente durante o tratamento e mostrou sua dificuldade em interagir com o desconhecido, deixando complexo seu equilíbrio entre momentos de saúde e de doença.

DESCRITORES: Criança. Câncer. Jogos e brinquedos. Enfermagem pediátrica.

\section{REVELANDO EL MUNDO DEL TRATAMIENTO ONCOLÓGICO ATRAVÉS DEL JUEGO TERAPÉUTICO DRAMÁTICO}

RESUMEN: Dirigido a comprender el juego de los niños en edad preescolar se someten a tratamiento para el cáncer a través del juego terapéutico dramático. Realizados sesiones de juegos terapéuticos dramáticos con cinco niños con cáncer, con edades preescolar, a partir de enero a mayo 2013. Procedieron a analizar el material de acuerdo con el marco de la fenomenología: análisis de la estructura del fenómeno. Análisis de las sesiones siguientes categorías surgieron: sumergirse en el mundo del tratamiento de la enfermedad y el cáncer y recordar al mundo sin la enfermedad. El estudio detenido que enfermarse de cáncer es un proceso que el dolor y el sufrimiento para el niño, lo que lleva a sentirse pequeño y frágil en comparación con las molestias de los numerosos procedimientos que se presentan. El juego terapéutico era un recurso importante para revelar cómo el niño con cáncer se siente durante el tratamiento y mostró la dificultad de interactuar con lo desconocido, dejando a su complejo equilibrio entre momentos de salud y enfermedad.

DESCRIPTORES: Niño. Cáncer. Juegos y juguetes. Enfermería pediátrica. 


\section{INTRODUCTION}

Cancer stands out because of its high incidence, being the second greatest cause of death in children and adolescents between one and 19 years of age. ${ }^{1}$ The child with cancer enters a complex world, and can see a path for treatment which is uncertain, painful, and prolonged; which changes her routine, and distances her from family members, friends and the home, weakening plans for the future, as well as making death a real possibility. ${ }^{2}$

Although cancer does not necessarily interrupt the process of child development, some physical and psychosocial restrictions imposed by the disease and by the treatment can delay it. Hence, the care for the child undergoing oncological treatment must provide physical, social, environmental and psychospiritual comfort. ${ }^{3}$

One study used computer games to help children with cancer deal with the stress of hospitalization, and concluded that the emotional conditions are essential in recovering health, both in the treatment and in the way in which the disease was consolidated in the child's imagination. ${ }^{4}$ With a focus on this care, which promotes the emotional integrity of the child with cancer, the health actions must also provide healthy growth and development. ${ }^{4}$

Children aged between three and nine years old were invited to express their experiences regarding cancer through pictures, and revealed that the disease determines times of discomfort related to the treatment, but also times of comfort linked to support from family members and from the health team, in addition to the distraction activities: playing, playing games, and reading. ${ }^{3}$

Play is a basic need for the child and it is through this that she acquires new knowledges in and of the world, discovers her individuality, and learns to distinguish between reality and fantasy. ${ }^{5}$ In her play, the child is transported to a world of imagination, this being characterized as a spontaneous, pleasurable and engaging activity which provides recreation, stimulation, socialization, dramatization of roles and of conflicts; and catharsis. ${ }^{6}$

Therapeutic play (TP) is a structured form of play which allows the child to relieve anxiety generated by situations which are atypical for her age, contributing to her being able to release tensions after experiencing these. ${ }^{7}$ Its objective is to allow the nurse a better understanding of the child's needs, to assist in the preparation of therapeutic procedures, and to allow the child to reorganize her emotions after difficult periods in her life. ${ }^{6}$

As a result, TP is not only a means of communication with and access to the child's world, but has also been shown to be essential in that it helps the child to cope with the reality of the disease, enabling her to understand and recover self-control in the light of adversities, being indispensable in her routine.

Considering the difficulties imposed by the disease and the oncological treatment in childhood, some concerns guided the undertaking of this study, including: How does the play of the child with cancer occur? What are the oncological treatment elements and situations manifested by the child in the play? What is the influence of the treatment on her routine? What are the repercussions of the disease in her physical and psychological development?

In the light of these questions, this study aimed to understand the play of the preschool age child undergoing oncological treatment through dramatic therapeutic play. It is highlighted that the investigation of this issue is fundamental for understanding this singular time, respecting the individuality and needs of the child with cancer, as well as contributing to reflection on the work of the nurse, regarding the planning of the care actions.

\section{METHOD}

This is a qualitative study, using the methodological framework and analysis of the structure of the phenomenon in place, which is inspired in Phenomenology as a philosophical school. The choice of the framework was made because this research approach considers the being in its uniqueness and seeks to understand the experience experienced by the subject, valuing the relations with the other and with the world. ${ }^{8}$

The study was undertaken in a support house for the child with cancer and hemopathies in the city of Campinas in the Brazilian state of São Paulo. The unit houses children and adolescents with cancer, from 0 to 18 years old, together with their companions, and has the capacity to shelter up to 56 children and adolescents with their respective companions.

The participants were five preschool-age children with cancer ( 3 to 6 years old), who were 
undergoing oncological, clinical and/or surgical treatment, and who were living temporarily in the support house. For choosing them, the following criteria were taken into consideration: to be of preschool age, to be living in the support house during their treatment up until their return home, and for the child to wish to play.

The sessions of dramatic therapeutic play (DTP) were undertaken individually with each child, only in the presence of the main researcher, as determined by the phenomenological approach for accessing participants, ${ }^{8}$ and took place in January-May 2013, beginning with the guiding question: "Shall we play at a child with cancer?"

A total of 26 DTP sessions were held, recorded digitally and transcribed in full, with average duration of 48 minutes per session. The number of sessions held with each child was determined by her presence in the support house during the treatment until she returned to her home, this being one limitation of the study, and by her desire to play. The children and their respective fictitious names, as well as their ages, sexes, diagnoses and number of DTP sessions, are described in Table 1.

Table 1 - Children who participated in the study. Campinas-SP, 2014

\begin{tabular}{|c|c|c|c|c|}
\hline Child & Age in years & Sex & Diagnosis & Number of sessions \\
\hline Sun & 04 & F & Acute lymphoid leukemia & 05 \\
\hline Star & 03 & F & Malignant tumor in the spinal column & 09 \\
\hline Fairy & 03 & F & Acute lymphoid leukemia & 07 \\
\hline Little & 06 & M & Adrenal gland tumor & 03 \\
\hline Light & 04 & F & Myosarcoma & 02 \\
\hline
\end{tabular}

In order to undertake the sessions, various toys were offered, such as: a family of dolls, toy cars, games, and domestic utensils, as well as toy versions of hospital materials: syringes, hypodermic needles, blood and urine collection bottles, adhesive tape, catheters, gauze, tourniquet, giving set, and bottles of normal saline among others, as recommended in the literature. ${ }^{6}$

A field diary was used for noting the aspects which the audio recorder was not capable of capturing, such as playing in silence. The number of participants in the study was not established beforehand, the sessions being ended when the content of the same responded to the researcher's concerns, so as to reveal the phenomenon in question. ${ }^{9}$

The analysis of the DTP sessions was undertaken in accordance with the theoretical framework of the analysis of the structure of the phenomenon in place. Firstly, each statement was transcribed in full, following which successive readings of the corpus were undertaken, the aim being to understand the experience as experienced by the subject. Following that, the researchers proceeded to idiographic analysis, with the aim of grasping the most significant parts of each discourse, so as to identify the units of meaning which represent the fundamental structures of the phenomenon. ${ }^{8-10}$
Immediately afterwards, through a previous categorization of the units of meaning, it was possible to develop a consistent description of the structure of the phenomenon in place, that is, nomothetic analysis; at this point, the units of meaning which had the same meaning, or which converged towards the construction of this study's thematic categories, were grouped. The organization of the significant aspects of play of the children with cancer makes up the concrete categories which reveal the phenomenon in question.

The research project was approved by the Research Ethics Committee of the Faculty of Medical Sciences of the Universidade de Campinas, under protocol n. 58949/2012, and was in accordance with the resolutions of the National Health Counsel, which regulate research undertaken on human beings. Those responsible for the children received clarification regarding the objective of the study and the preservation of the children's anonymity, and signed the Terms of Free and Informed Consent. All the children who participated consented verbally.

\section{RESULTS AND DISCUSSION}

The following categories emerged from the understanding of the play of the preschool children undergoing oncological treatment through Dramatic Therapeutic Play: Immersing oneself 
in the world of the disease and the oncological treatment; and Remembering the world without the disease.

\section{Immersing oneself in the world of the disease and the oncological treatment}

The child with cancer enters a world with numerous invasive and painful procedures, obliging her to experience periods of the unknown, of stress and uncertainty. ${ }^{11}$ However, it was observed that even small children with limited language resources were able to demonstrate, through the DTP sessions, how they perceive the routine which they experience.

The idea that preschool-age children do not understand various issues, including the diseases which they suffer from, was clarified in this study; the play revealed that, although the children do not understand cancer in the same way that adults do, they understand it in relation to specific characteristics of the oncological treatment: [...] Aunty! Let's hurt the baby? Let's do this one, shall we do it? It doesn't hurt here! That's it! (Star, 3 years old).

It is possible to grasp, from the discourses, the child's perception regarding cancer, the same being understood as episodes which provoke pain and suffering. It was also observed, through the imaginary situation dramatized in the DTP sessions, that the child's current feelings are linked symbolically to the anxiety which results from the invasive procedures, taking into account the child's knowledge regarding the stages of the therapeutic process.

The oncological treatment gives rise to numerous feelings in the child, above all as a result of the undertaking of the painful procedures and the changes in her routine, such as distance from family members, friends and her home. Nevertheless, these feelings provoke fear regarding the uncertain and obscure future normally permeated by distress, which can entail harm to the child's well-being. . $^{212}$

Once they have entered the world of oncological treatment, the children come to understand cancer as a disease which demands specific care and procedures, and they recognize the distressing trajectory which they pass along - and, as a consequence, they experience the pain, inconvenience and suffering which result from this therapy.,5

[Conversing with the researcher] Look at my bruise, Aunty! I got vein and it burst. So it made liquor and injection in my bottom (Sun, 4 years old).
[Holds the syringe and needle] Yesterday I had one of these, one of these there in the hospital. And I cried, how I cried. Yes, there in the hospital. I got the needle in my arm and had another, I did (Fairy, 3 years old).

[Picking up a nasogastric catheter] This is for putting in your nose. I've already had one of these put in, it is difficult to breathe (Little, 6 years old).

It can be identified in the discourses that experiencing these procedures is not an easy situation for the child; on the contrary, it gives rise to a series of negative feelings, which can trigger behaviors of insecurity and vulnerability, including regarding the health professional, given that the child perceives the health professional as the source of pain and suffering.

Leave it here, Aunty, did you see? Ready. You mustn't touch this, okay?! I am the doctor, okay?! I am the doctor who causes pain. The doctor causes pain. (Star, 3 years old).

Look, Aunty, it was the nurse who did it! It hurts here. The needle made a hole. It was the nurse (Fairy, 3 years old).

In the midst of the universe of being ill, present in the routine of the child with cancer, at all times she travels along a path seeking to adapt to and understand that point in time. One study undertaken with Chinese children and adolescents with cancer being treated as inpatients, aged between nine and 16 years old, aiming to examine the coping strategies used, observed that there are differences involving the culture, as the strategies used are related to emotion, with a view to self-control; to the contrary of Western children who use strategies focusing on the problems. ${ }^{13}$

As a result, the children in this study seek to overcome the stress and anxiety generated by the treatment through dramatizing situations experienced in their day-to-day, verbalizing some phrases used routinely by the health professionals. In another study, children who participated in TP sessions also repeated phrases used by the health professional, requesting the doll to collaborate for the success of the procedure. ${ }^{14}$

[Dramatizing venipuncture on the doll] Close your hand. Do it like this, look. Be quiet, don't move, take the needle and take it again, then, you won't go away! We are going to have to hold you. [...] Whoa, you moved, what can I do! Everybody is here holding you to not move. Your leg, your arm and your face. It hasn't burst it, don't move, relax. Relax, don't move! Now 
you don't pull it out. I'm going to put some medicine into your vein. Careful, don't move, don't move! (Sun, 4 years old).

In this way, it is identified in the above discourse that the way in which the child perceives the care provided by the health team, allied to her inability to deal with new and conflicting situations, causes the experience to be understood in a sad and painful way. ${ }^{4}$

Although many invasive and painful procedures cannot be avoided, they can be attenuated through the use of a simple vocabulary and the use of play-based ${ }^{15} /$ educational $^{16}$ interventions, which allow the child's understanding, encouraging her to express feelings, doubts and fears.

The use of the toy as an instrument of guidance for therapeutic procedures allows the child to feel safer and more at ease, allowing the understanding of the situation and, consequently, greater calm. In addition to this, the play helps to clarify mistaken concepts and fantasies which form part of the child imagination ${ }^{6,17}$

In the oncological treatment, the venipuncture for collecting specimens for tests or administering chemotherapy agents is one of the procedures undertaken the most. It creates great fear and stress for the child..$^{18}$ At the beginning of the DTP sessions, one can note that the children show - apart from the fear - a rejection of the object "needle".

[Dramatizing the venipuncture on the doll] Medicine. Hold it. You have to hold the needle. Aunty, you have to look for the needle. Get it for me please. Put the needle here. Put it in, put it in. I'm not going to put it in. I'm scared of needles. Put it in here, put it in. (Fairy, 3 years old).

[Exploring the toy box] There are more things for injections, aren't there? And this needle here, for the catheter. Oh, I'm playing with that, dear God, I am scared! (Sun, 4 years old).

Feeling scared is common and makes the daily routine more uncertain and threatening; however, little by little this fear and worry regarding the object of the needle reduced, giving way to skill in handling this material and the need to use it during the dramatizations.

One study undertaken with children aged between six and 12 years old used fliers with attractive images during blood sample collection, which resulted in reduction in the levels of pain and anxiety. ${ }^{19}$ With preschool age children, on the other hand, distraction was used through the use of a laptop during venipuncture and the intervention also reduced the response to the pain. ${ }^{20}$

The children gradually revealed knowledge of the materials and procedures related to the oncological treatment, showing that this is now the world in which they live. As a result, one can perceive that the children have come to demonstrate greater dexterity in the use of hospital objects during the dramatizations of specific procedures.

The child submitted to invasive procedures tends to cope better with the period of treatment when she is already familiar with the materials and equipment used in her therapy, as well as when she handles the same. ${ }^{5}$

[Conversing with the researcher] Me!... I put in the catheter, I don't have any more veins. All of them were burst! (Sun, 4 years old).

[Dramatizing prescribing and setting up chemotherapy on the doll] Be careful. Look! Medicine. You going to have chemo. Chemo over six hours. [...] He knew that he had to have more chemo, a lot of chemo. So much chemo. I'm going to let you relax, Aunty, and then I will get your vein. Let me write down in your notes, Aunty. All right, enough chemo. (Sun, 4 years old).

The treatment entails a strong impact on the life of the child who experiences child cancer.

The consequences of the situations of stress experienced by the children lead to the their difficulty understanding the need for the therapy; however, the symbolic power of the toy makes it possible to master the situations which threaten them, making them "owners of the situation" when they manipulate the hospital objects and report the stages of the treatment.

The experiences related to the hospital procedures emerged in all the DTP sessions, reflecting the child's understanding regarding the current period through which she is living, some of these procedures being highly detailed by the children during the dramatizations.

[Ties the tourniquet on the doll's arm, and with the trigger finger acts out seeking a vein for the venipuncture] We will have to find another vein, in this one the needle has penetrated the other side of the vein. Come here, Aunty, stay here. Let me see if I can find it here. I have found a vein here. Let me see if this time the other wall of the vein won't be punctured (Sun, 4 years old).

[Explaining the procedures to be undertaken] You're going to have little dot, okay [blood test]. You're going to have little dot, you are going to 
have liquor, little dot, vein, vein and pass for consultation [...] Then it's going to have another liquor. Then you are going to do liquor, little dot, vein pass for the consultation and then you go home. Then you are going to take this medicine as fast as you can to go home. You are going to do everything before you go home (Sun, 4 years old).

In repeating on the toy all the situations which cause stress, the children come to master the objects which are outside their reach and compensate for the pressures which they suffer in the day-to-day of the treatment. ${ }^{2}$ Nevertheless, on some occasions, these repetitions also suggested the relaxation of the child, it being the case that after the dramatizations, they appeared relaxed and calm, even smiling when they finished playing. ${ }^{3}$

[Takes a toy knife and acts out making a splint for fixing the venous access in the doll's arm] There, found it. Splint! Splint. It's a splint. Yes, It is to lose vein. Ready. That's it, that's it! (Star, 3 years old).

[Dramatizes cutting the doll's tummy with the toy saw] Can you do surgery with a saw on the girl? I am doing surgery on the girl (Little, 6 years old).

Little, when he acted out the operation on the doll, was waiting for abdominal surgery for removing a tumor. In conversation with his mother, on the days prior to the surgical procedure, he was apprehensive and distressed, going so far as not to accept to play with his own personal toys. After the DTP session, however, his mother stated that he had become calmer and more tranquil, returning to playing with his toys - and that, in particular, that night, he had slept without the help of any sleep-inducing medication.

The capacity which toys have to enable children to reflect on the situations they are experiencing and, in addition to this, to act out significant times for themselves was evident. The more the child repeats an event which is significant for her, the more her tensions are relieved and, consequently, her anxiety is reduced. This is catharsis. $^{7}$

Progressively, the children created imaginary situations related to the treatment environment, as one can observe in the play below.

[Dramatizing setting up a drip on the doll] Look Aunty, leave her here, she is on a drip. She is ill. Ill! (Star, 3 years old).

[Dramatizing giving medications to the doll] Omnibiotics [antibiotics]. She is ill (Light, 4 years old).
[Dramatizing taking blood from the doll] Taking blood from the doll. Because she is doing tests. Look, she's going to take medications. She took it. It is medicine. She is ill. She has a sore throat. (Fairy, 3 years old)

[Explaining the procedures to the doll] And now you are going to have a drip! Go on, this is medicine. This medicine is for pain [pause] It is for pain, so it is, for getting better. Keep still, okay. Today, your vein is good (Sun, 4 years old).

One can observe that the children use these incessant dramatizations in order to adapt to the limitations imposed by the disease, so as to strengthen themselves to cope with and master this new context, which contributes to them understanding the situation and regaining self-control. In this way, TP makes it possible to relieve the anxiety and stress generated by the situation of illness, offering the child the opportunity to understand her actual situation. ${ }^{17-18}$

It is made clear that the routine of the child changes and, as time passes, the actions come to be understood in a more natural and spontaneous way, as if this situation were already part of the child's routine. As a result, time and the familiarity with the situation of illness, in a certain way, allow the child greater control over the events, promoting the forming of resources for more active coping.

[Explaining the procedures to the doll] I'm going to have to set up a drip. Because you're going to have to stay in hospital. Your fever has gone down! [...] My immune system is low, you're not eating, just having bottles. Immune system. The immune system is a little low. Now we have to give some medicine (Sun, 4 years old).

[Explaining to the researcher the procedure which she is to undergo] Tomorrow I am going to have a drip set up. In the hospital. It will puncture here, look (Fairy, 3 years old).

In addition to the new way of playing that was brought by the disease and the oncological treatment, the children in this study manifested their understandings regarding the hospital, recognizing it as an environment of treatment, with the undertaking of invasive and painful procedures. The hospital, for the children, is seen as an environment which is different from their normal one, which is responsible for the breaking away from their daily routine and from the physical and emotional relationships with family and friends. ${ }^{5}$

He went there, to the hospital. [...] It is that big one, where they get your veins all the time! So it is that one (Sun, 4 years old). 
[Dramatizing setting up a drip on the doll] On a drip! That is how it is in hospital, isn't it, Aunty? (Little, 6 years old).

The children feel that they have become familiar with the hospital and the therapeutic procedures undertaken there; however, it is in this environment that numerous stressing situations take place, which can entail harm to the child's global development. Nevertheless, the situation can be alleviated when the child perceives the support and presence of an adult who demonstrates acceptance and who encourages the child to exteriorize her feelings, as well as when the child is encouraged to continue her play activities. ${ }^{18,21}$

This study's results made it possible to distinguish the specific characteristics of the oncological treatment and how this makes itself present in the child's play, as in all the DTP sessions, they represented the procedures experienced in their routine intensely. Nevertheless, it was not only the world of disease and treatment that was represented in the play; also presented was the world without the disease.

\section{Remembering the world without the disease}

In this study, it was observed that there were a few times when the children wanted to play at domestic situations, as the situations related to the disease and the treatment were represented incessantly in all the sessions, evidencing the impact which cancer in children has on the child's behavior.

The oncological treatment imposes on the child the need to leave the family environment, including most of the habits of daily life, routines and rituals, personal objects and games. The disease entails loss of the child's liberty, her day-to-day is interrupted, and the pleasures of childhood come to be substituted by a new context. ${ }^{2,5,12}$ Although few in number, there were times in which the child showed a wish to relive situations of family routine, which evidences that the illness, despite having an impact, is not capable of neutralizing the child's history prior to the diagnosis of cancer.

[Inviting the researcher to play] I am watching cartoons, shall we watch cartoons? You can be my brother [laughs]. I am watching cartoons with my brother. I am a baby. [...] It's my baby. It's sleeping. It's quiet, I will make some food. Bye-bye (Star, 3 years old).

[Playing with a toy iron] I will thingy the dress now. [...] This thing burns your hand! Hold it here, because it is hot (Fairy, 3 years old).
Play is the child's job, it is a serious act which develops autonomy, causing the child to explore the world, overcome barriers, know things, learn things and understand rules, and is a way to communicate. ${ }^{5}$ Through playing, the child simulates another world, which is hers alone, distancing herself from the world of the adults. It is a world where she can exercise sovereignty: she can be a king, a father, a teacher or a hunter. This perspective takes into account, let one say, her personality, giving it a striking characteristic and, at the same time, offering her new powers. ${ }^{6}$

While she plays, she deals with the unknown, aggressive impulses, organizes the social and emotional relationships, and has the opportunity to experiment with various objects, exploring them, discovering them, and understanding them. The toy, in addition to satisfying desires, acts as an element for mastering a frustrating context. ${ }^{22}$

[Dramatizing playing at cooking] A cake! Now we have to find the top of the oil bottle! Aunty, shall we mix the cake? Do you want me to mix it? Mixed it! I will mix it again. Are you hungry? Anything else? Do you want all of my cake? Eat this cake! Anything else? (Fairy, 3 years old)

I am going to make vegetable soup. Look at the watermelon, just that. Banana, that's not going to fit in. Let me take out the strawberry. That's right. Ready, it is ready. Now, I'm going to make some ice cream, I will put in strawberry and pineapple (Little, 6 years old).

It was observed in the discourses that when she plays, the child learns, consolidates thoughts, and transforms her time and space, adapting to the changes in her actual life and also being able to incorporate new knowledge, skills and attitudes. During times of play, the child can think freely, and can dare and imagine, and can exercise the cognitive, social and affective aspects, as well as strengthening bonds. ${ }^{22}$

Play was shown to be an instrument for controlling stress, offering the child the opportunity to make choices. Through playing, the ill child is able to bear the difficult context of living with the disease and the treatment, regaining self-confidence and growing in the face of situations which cause her stress. ${ }^{2}$

\section{FINAL CONSIDERATIONS}

Based on this study's results, it was possible to learn that the children of preschool age feel very frightened and insecure in the face of the painful interventions undertaken during the oncological 
treatment. Psychological and social relationships are significantly shaken and may sometimes interfere in the children's global development.

The successive dramatizations of therapeutic situations, including involving the mastering of hospital objects, revealed the children's difficulty in achieving balance between experiencing times of the routine prior to the disease and times which are exclusive to the treatment, between normalization and anxiety, between health and the disease.

Therapeutic play was shown to be a strategy with potential for promoting care to the children undergoing oncological treatment. In the play, the children grew, freeing themselves from this condition in which they were submissive and small.

As the sessions went by, the children began to interact differently with the researcher, demonstrating a closer, more affective, friendly relationship. This closer bond made it possible for the repercussions of the disease and the oncological treatment to be revealed through the play; thus, the sessions made it possible to understand that the treatment represents - for the children - an experience which is full of pain and suffering.

The promotion of means of communication and relating which are appropriate to childhood during the care can help the children to face the suffering resulting from the oncological treatment. In this case, for the children who participated in this study, emphasis is placed on the use of therapeutic play, causing it to achieve its recreational, cathartic, socializing, stimulating, therapeutic and learning function.

This study has implications for nursing practice, in the sense of encouraging the inclusion of therapeutic play as a nursing intervention in the routine of caring for the child with cancer, in such a way as to consider the needs - intrinsic to childhood - which are added to the impact caused by the cancer, as well as the importance of teaching therapeutic play on undergraduate nursing courses.

This study's relevance lies in the fact that it made it possible to understand the play of the preschool age child undergoing oncological treatment, based on her experiences and actions in the world, knowing her feelings and her possibilities for coming-to-be; that is, therapeutic play enables children with cancer to be heard.

\section{REFERENCES}

1. Ministério da Saúde (BR). Instituto Nacional de Câncer. Estimativa 2014: incidência de câncer no Brasil [Internet]. Rio de Janeiro (RJ): MS; 2014 [citado 2014 Mai. 26]. Disponível em: http:/ / www.inca.gov. br/estimativa/2014/sintese-de-resultados-coment

2. Hildebrand A, Clawson M, Alderfer M, Marsac M. Coping with pediatric cancer: strategies employed by children and their parents to manage cancerrelated stressors during treatment. J Pediatr Oncol Nurs. 2011; 28(6):344-54.

3. Ângstrom-Brännström C, Norberg A. Children undergoing cancer treatment describe their experiences of comfort in interviews and drawings. J Pediatr Oncol Nurs. 2014; 31(3):135-46.

4. Li WH, Chung JO, Ho EK. The effectiveness of therapeutic play, using virtual reality computer games, in promoting the psychological well-being of children hospitalized with cancer. J Clin Nurs. 2011; 20(15-16):2135-43.

5. Melo LL, Valle ERM. The toy library as a possibility to unveil the daily life of children with câncer under outpatient treatment. Rev Esc Enferm USP. 2010; 44(2):517-25.

6. Ribeiro CA, Borba RIH, Melo LL, Santos VLA. Utilizando o brinquedo terapêutico no cuidado à criança. In: Carvalho SD. O enfermeiro e o cuidar multidisciplinar na saúde da criança e do adolescente. São Paulo (SP): Atheneu; 2012. p.127-34.

7. Green CS. Understanding children's needs through therapeutic play. Nursing. 1974; 4(10):31-32.

8. Martins J, Bicudo MAV. A pesquisa qualitativa em psicologia: fundamentos e recursos básicos. São Paulo: Moraes; 2004.

9. Giorgi A. The descriptive phenomenological method in psychology. Pittsburgh (US): Duquesne University Press; 2009.

10. Giorgi A. Difficulties encountered in the application of the phenomenological method in the social sciences. Aná Psicológica; 2006; 24(3):353-61.

11. Fortier MA, Wahi A, Bruce C, Maurer EL, Stevenson R. Pain management at home in children with cancer: a daily diary study. Pediatr Blood Cancer. 2014; 61(6):1029-33.

12. Souza MLXF, Reichert APS, Sá LD, Assolini FEP, Collet N. Stepping into a new world: the meaning of sicken for the child with cancer. Texto Contexto Enferm [online]. 2014 [acesso 2015 Jul 04]; 23(2):391-9. Disponível em: http:/ / www.scielo.br/scielo.php?pid=S0104-07072014000200391\&script=sci_arttext

13. Willian Li HC, Chung OKJ, Ho KYE, Chiu SY, Lopez $\mathrm{V}$. Coping strategies used by children hospitalized with cancer: an exploratory study. Psychooncology. 2011; 20(9):969-76. 
14. Medeiros G, Matsumoto S, Ribeiro CA, Borba RIH. Brinquedo terapêutico no preparo da criança para punção venosa em pronto socorro. Acta Paul Enferm. 2009; 22(spe):909-15.

15. Cooper V, Nelson R. The impact of play and recreation on reported pain levels in children with cancer. Ther Recreation J. 2015; 49(1):84-86.

16. Wu LM, Chiou SS, Sheen JM, Lin PC, Liao YM, Chen $\mathrm{HM}$, et al. Evaluating the acceptability and efficacy of a psycho-educational intervention for coping and symptom management by children with cancer: a randomized controlled study. 2014; 70(7):1653-62.

17. Maia EBS, Ribeiro CA, Borba RIH. Compreendendo a sensibilização do enfermeiro para o uso do brinquedo terapêutico na prática assistencial à criança. Rev Esc Enferm USP. 2011; 45(4):839-46.

18. Artilheiro APS, Almeida FA, Chacon JMF. Uso do brinquedo terapêutico no preparo de crianças pré- escolares para quimioterapia ambulatorial. Acta Paul Enferm. 2011; 24(5):611-6.

19. Inal S, Kelleci M. Distracting children during blood draw: looking through distraction cards in effective in pain relief of children during blood draw. Int J Nurs Pract. 2012; 18(2):210-9.

20. Yoo H, Kim S, Hur HK, Kim HS. The effects of an animation disctraction intervention on pain response of preschool children during venipuncture. Appl Nurs Res. 2011; 24(2):94-100.

21. Silva LF, Cabral IE. Cancer repercussions on play in children: implications for nursing care. Texto Contexto Enferm [online]. 2014 [acesso 2015 Jul 04]; 23(4):935-43. Disponível em: http:/ / www.scielo.br/scielo.php?script $=$ sci_ arttext\&pid=S0104-07072014000400935

22. Winnicott DW. O brincar e a realidade. Rio de Janeiro (RJ): Imago; 1975. 